\title{
Godfrey Baldacchino
}

University of Malta, MALTA

\section{'But What Exactly Does the Directive Say?': The Role of EU Acquis Experts in Industrial Relations}

ABSTRACT - Expertise suffers booms and troughs like any other market good. The supply and demand for specialists, and the nature of the specialisms required, change in accordance with the exigencies of time and place. A particular breed of specialists is on the ascendant as a number of countries seek to confront, accept or adapt to the massive body of obligations of European Union (EU) law (referred to as the acquis communautaire) in the context of accession negotiations. In the dozen applicant states, a typically very small number of specialists in such matters is suddenly sought after as government consultants, media commentators, technical reporters and impact assessors. This article adopts a political sociology perspective in seeking to assess the influence of such technical experts on the politics of national industrial relations. It argues that such experts do somehow infect the opinions of interest groups, as well as their policy with respect to the EU in particular. Such is more likely to be the case when such interest groups suffer from a 'knowledge gap' and do not enjoy the services of professional EU specialists 'in-house'. Primary data are drawn mainly from autobiographical material; but the article attempts to propel a cross-national debate on the relevance of the experience and its analysis.

\section{Introduction}

For most, it was already a foregone conclusion. When, in autumn 2000, a team of 'three wise men' was engaged by the European Commission to examine the human rights record of Austria's political establishment, and particularly the behaviour of its ruling coalition, it was clear that a neat solution had been found to end Austria's political isolation in western Europe, stop the increasing resentment against the EU among Austrian citizens, and thus save the EU from further embarrassment. Irrespective of the details of a much publicized case, this was yet another example of the often unclear dynamics between expertise and political incumbents in 
crafting policy at a European level. On this particular occasion, experts had been deployed to legitimize a U-turn in political strategy. Thus, the experts, in fewer than 1000 words, provided the objective and independent assessment to corroborate and recommend a particular course of political action, which (not coincidentally) was exactly the one being, not quite silently, contemplated.

\section{This Article}

This article explores a similar tension between experts and political actors in relation to the sphere of industrial relations. The contention is that responsibilities and agendas related to EU affairs, particularly the social policy obligations arising from EU membership, are leading to an ascendancy of the unaccountable and 'scientific' expert in European industrial relations, certainly at a national level. It becomes, therefore, increasingly naive to support a classical model of nationally based industrial relations which presupposes the social partners as the key actors. Having the characteristics of a supranational and transnational European class, EU experts may be influencing the tenet and substance of industrial relations much more than we may care to admit.

This article first documents the manner in which a specific group or class of experts assumes authority and legitimacy in dealing with EU matters. It next seeks to describe how such a group or class of individuals gets to influence the tenor, nature and dynamics of industrial relations on a national basis, and with what effects. Lastly, it reviews the impact of such 'third-party experts' on European industrial relations generally.

\section{The EU Newspeak}

Directives, acquis, avis, recommendations, regulations, derogations, transitional periods, communications, Commission, Council, Parliament, qualified majority, Treaty, Maastricht, Brussels, Amsterdam and so on: this is a sample from the large collection of terms which easily boggles the mind of the novice to European Union (EU) matters, but which must become staple fare to anyone venturing to develop some understanding of how the EU works. The large mass of literature, case law and other material concerning the EU is nothing short of awesome. The acquis communautaire is claimed to be some 80,000 pages long, and growing every day.

There are now a record 13 applicant states which are having to integrate this corpus of regulation and practice into national legislation in the process potentially leading to eventual EU accession. 'Social Policy and Employment' is the title of one out of the 31 chapters of the EU acquis, 
and its contents are of direct concern to self-employed, waged or salaried workers, employers and their representatives.

\section{Inspiration}

I am indebted for the inspiration for this article to my emerging status as an 'expert' on European social policy in my own small sovereign state, Malta. Ever since the re-elected Nationalist government reactivated Malta's bid for EU membership in autumn 1998, the country has found itself on a roller-coaster of meetings, deadlines, implementations, legal drafting, administrative reform, impact assessments and so on, all associated with Malta's self-appointed obligation to conform to the EU acquis by a deadline of 1 January 2003. Meanwhile, most local social, political and economic players are engaged in an intensive media campaign to shift the electorate either for or against membership, in the run-up to a keenly anticipated referendum on EU membership, due late in 2002. Malta thus presents itself as the smallest country among the set of 13 'first wave plus second wave' applicants, the one with the strongest official opposition to EU membership among all applicant states, ${ }^{1}$ as well as one trying to undergo the transition to qualify for membership in a fairly short time. ${ }^{2}$

\section{A Personal Note}

As a university-based sociologist working in the sphere of labour relations education and research, I had taken an obvious interest in EU social policy over the years, and had organized a variety of educational visits for Maltese trade union leaders in connection with the EU. ${ }^{3} \mathrm{My}$ monthly contributions to a local newspaper, focusing largely on labour relations issues, increasingly considered EU developments. In spring 1999 , I was genuinely surprised to be invited to sit as one of six national 'expert core members' of the Malta-EU Steering and Action Committee (MEUSAC), the institution now responsible for preparing Malta's negotiating positions with respect to the European Commission and enjoying wide public representation, though with one glaring exception. ${ }^{4}$ In this capacity, I have also participated as a member of the Maltese government delegation to a couple of acquis screening sessions in Brussels. I have been asked to prepare reports for both major trade union organizations on the implications of adopting Chapter 13 of the acquis in Malta, and participated in various popular and academic fora (at the university, road shows, on radio and on television) to expound on such matters.

In autumn 1999, I was invited by the Malta Employers' Association (MEA) to carry out a study comparing the EU's social policy, labour law 
and industrial relations acquis with that in force in Malta, identifying the differences and recommending action. I accepted the assignment in a personal capacity, also because this was the first time that the MEA had approached me for any such commission; as a person associated with trade unions and with declared labour sympathies, a distancing from and by the MEA was to be expected. Yet, it seems that my EU 'expertise' (and perhaps the unavailability of any decent local alternative) was enough to oblige the MEA to override its apprehensions in my regard and to place its trust in my competences.

My report was fully endorsed by the MEA - to the extent that it was published without any changes from the original manuscript (Baldacchino, 2000). The report has now become the official MEA position paper for making representations to the Malta government as to where Maltese employers stand with respect to the 'social policy' implications of eventual EU membership.

I deliberately concluded my study with a national sample survey of employer perceptions, and therefore what I was proposing was couched as a natural consequence of fieldwork whose validity and merits could hardly be contested. I was, nevertheless, quite overwhelmed by the reactions of the MEA leadership in 'coming round' to the recommendations I had tabled. It was this very personal, ongoing experience which obliged me to consider the role of 'EU experts' in crafting national industrial relations and social policy. This article is, therefore, autobiographical in many instances and relies considerably on such 'primary data'.

\section{The Industrial Relations Setting}

There seems to be a fair degree of consensus on the fact that industrial relations concerns the exercise of job regulation and the assertion of some kind of security, stability and predictability at the workplace, for the mutual benefit of employers, management, employees as well as 'thirdparty' stakeholders such as consumers and governments. A focus on such a state of, albeit continually reconstituted, 'order' (for example, Strauss et al., 1971: 104) or 'governance' (Streeck, 1998: 15) may, however, jaundice any assessment of departures from such a virtuous state (such as any struggles on the nature and extent of labour control (Hyman, 1975: 26)) as dysfunctional, anomalous or infectious. A micro-based analysis which focuses on the behavioural and political strategies and counter-strategies of labour and management has become a specific strand of industrial relations research in recent decades, this being in part a healthy reaction to the stultifying functionalism of order-obsessed approaches. Meanwhile, the ambit of the study of job regulation has expanded to take on board comparative, transnational and European processes (as the articles 
in the European Journal of Industrial Relations would attest), apart from more specifically national, sectoral or regional developments.

What is often forgotten in this scholarly literature is that the key players of industrial relations are not just the social partners and their representatives. The industrial relations systems paradigm established by Dunlop (1958), an almost pure example of the bias of modernity, remains particularly solid. It has only been somewhat challenged lately by pleas to incorporate socially marginal groups, such as women and homosexuals (Dabscheck, 1995; Piore, 1995), as well as 'end-users', such as customers (Bellemare, 2000). Yet, often lurking in the shadow of the theory, there exists a motley entourage of 'free-floating intellectuals' (Dahrendorf, 1964: 225 , after Weber) to whom industrial relations is also their business, though in a markedly different sense. Indeed, the actual regulation of work may be significantly determined by authoritative personnel who may have no direct stake in the outcome of their counsel. Far removed from the 'contested terrain' of the workplace, key decisions and positions may be taken in the offices of consultancy firms, in the corridors of law courts, or in the academic offices of universities. Such 'outsiders' (Perlman, 1928), members of the intelligentsia, 'have the capacity to speak (uneasily) for others' (Frow, 1995: 164). In such deliberations, whether enterprise (micro-) based or nation (macro-) oriented, an analysis of the role of 'experts' has been surprisingly, and I would add uncomfortably, absent. There is definitely room for unease here, and it is the intention of this article to start to 'unpack' the reasons for such discomfort. On the agenda, therefore, and in agreement with Bellemare (2000: 384-5) is the problematization of the notion of the 'actor' in industrial relations.

\section{Defining the Experts}

By 'experts' I mean individuals who are not directly involved in industrial relations (they are not representatives of labour, nor of capital, often not even of the state), but who, nevertheless, play a very important role in suggesting, even determining, the actual unfolding of industrial relations between any combination of these three groups. They obtain and use their influence by virtue of the combination of knowledge, skill qualification, experience and track record in industrial relations and related areas - a portfolio which renders them and their advice naturally acceptable to one or more of the social partners. Like the older professions (archetypically, medicine, law and theology), and like the new middle class to which they typically belong, the market capacity of most of these experts is almost totally dependent on claims to 'esoteric knowledge', alias technical or intellectual expertise (Milner, 1999: 157). Such individuals can wield disproportionate power: they are not generally accountable to a constituency 
and are, therefore, not obliged to expose themselves to public or membership scrutiny; their expertise can provide them with a special legitimacy and a positional advantage in any argument in which they are deemed to be versed; they can, and do, with tact and diplomacy, exert a significant influence on policy- and decision-making. Much like dei ex machina, their exclusion from industrial relations scrutiny and analysis may only help to augment their power and almost to mystify their role. The outcome of bargaining rounds, the handling of an impasse, the interpretation of an award - so much can depend on such 'significant others'. Conversely put, the leverage and bargaining power of a social partner may depend considerably on the wisdom and shrewdness of its team of experts. The trade union leader, the general manager, the labour director, these may be merely the front line of a human resource machinery which is obliged to depend much more on its concealed professional cadres than one would care to admit. Such an uneasy dependence is likely to increase with an expanding corpus of knowledge, laws, regulations, case law, administrative procedures and other provisions governing industrial relations. A potentially disabling process of professionalization (Illich, 1977)?

Who are these individuals? They include: (a) lawyers versed in labour law, who must habitually defend their clients or press their case in court, tribunal or labour commission hearings and sittings, all the more so in cultures and environments which thrive on litigation; (b) partners in accountancy firms, industrial relations and human resources consultants who advise their clients on strategic and tactical issues; (c) influential and charismatic labour officials from state departments, state ministers and other seasoned arbitrators, conciliators and mediators who develop a working relationship with the social partners; (d) industrial relations academics and scholars who may actively involve themselves, or else be called upon to support the planning and policy-setting mechanisms of one or more of the same social partners; and (e) researchers and other enterprising individuals who may have a specialization in a particularly relevant field of study. Of course, such identities may overlap or come together in one and the same person.

This approach to industrial relations processes draws obvious parallelisms with elitist political theory. There is the same toning down of the discretion often assumed to lie at the hands of elected political actors and their fora; there is a sinister recognition that certain groups, or classes, of actors have an ingrained endurance and a position of power from which they are not likely to be easily dislodged, even in the wake of the 'changing of the guard' normal of democratic politics; there is a fatalistic understanding that such resilient actors have the ability to distort and shape both agendas and outcomes, in order to preserve and advance their own distinct interests. Unlike Plato's guardians, Veblen's technocrats and Mannheim's intellectuals, such EU experts may be gifted, but are not 
necessarily selfless people. As market players, experts have a material interest in the virtues of scarcity; as opinion formers, they may have a prowess in manipulation (Lasswell, 1911).

\section{The Evolution of Experts}

Experts have been defined as depositories of 'effortfully acquired abilities' (Bereiter and Scardamalia, 1993: 3). They tend to come and go, accompanying waves of specialization and discovery, and they tend to disappear (not without some last-ditch, desperate, rearguard action) into the background when their competencies become popularized and deprofessionalized or otherwise lose their relevance and glamour. Experts exercise market power and political influence in inverse ratio to the number of their cadre and in direct proportion to the novelty, scope and duration of the demand for their 'core competence' from the wider society. ${ }^{5}$ They may exercise deliberate closure tactics to restrict access to that intellectual capital which is the source of their privilege (Murphy, 1986).

The EU has its own impressive discourse and thus requires its own compendium of literacy and operacy skills. Laffan (1997: 12) refers to such a discourse as part of the symbolism necessary to create that imagined community' which is the invention of 'Europe'. This unique, transnational mechanism imposes a powerful obligation for an understanding of its internal workings on its members and (at least some of) their citizens: first, in order to conform to legal parameters and minimum standards; second, in order to tap EU resources and funds; third, in order to harmonize administrative practices and procedures; fourth, in order to participate fully and proactively in the EU's various decision-making structures and thus have a say in determining policy.

The EU has many of the characteristics of a 'mock bureaucracy' (Blau, 1968). It functions through highly complex procedures which are not only public and official, but also implicit and undeclared. It is also clear that an effective relationship with the sophisticated mechanisms of EU governance (both in terms of meeting obligations, but perhaps more importantly in terms of tapping its vast resources) depends on a familiarity with the unwritten rules of the game, or at least an ability to 'learn the ropes': how to develop networks and cultivate relationships which may potentially and eventually deliver.

\section{A Heavy Burden}

While citizens at large may profess ignorance and confess bewilderment at the panoply of EU-related and EU-dictated detail, practically all collective 
groupings, such as civil servants, farmers, environmentalists, industrialists, traders, customs officers, academics, trade unions, and professional associations, should (or must?) at least come to terms with the variety of ways in which the specific corpus of EU legislation and practice will have an impact on their behaviour. It is clearly in their interest to do so. Furthermore, it is also in their interest to have effective lobbying mechanisms infiltrating the corridors of Brussels and Luxembourg - finding out what is going on, reacting quickly to events, establishing a sympathetic ear in a strategic location and so on.

Similar obligations now loom for 12 of the 13 applicant states (the six 'first wave' Luxembourg summit applicants (1997) and the six 'second wave' Helsinki applicants (1999), but excluding Turkey) as they proceed with their negotiations with the European Commission on each chapter of the acquis with the purpose of achieving eventual accession to the EU. What is, however, different from previous enlargement exercises is that while applicant states are (generally speaking) the least prepared to take the acquis on board (certainly by comparison with the last enlargement of 1995), they are, nevertheless, technically expected to conform to an acquis which continues to grow ever more awesome.

Naturally, existing EU Member States have the benefit of advance warning and foresight of any new obligations by virtue of their involvement in the (usually lengthy) process which leads eventually to the introduction of the obligation itself. Applicant states, in stark contrast, are by definition presented with a fait accompli. This does not only mean that the tempo of compliance must be faster, it also means that the generation of local expertise to implement any EU-dictated measures and to come to terms with how to 'manage' the behemoth (in the dual sense described above) must also be faster. The European Commission itself expresses concern, at least on an official level, at the probable vacuum of understanding and competence by questioning what it calls the 'administrative capacity' and level of preparedness of applicant states to conform to their eventual obligations in accordance with the given acquis. ${ }^{6}$

This creates the scenario which will naturally and quickly spawn 'experts' - be these real 'heavyweights' or incompetent 'pseuds'. While expertise may be easiest to identify 'when it differs most dramatically from what ordinary people can do' (Bereiter and Scardamalia, 1993: 6), less striking differences may have a surprisingly similar effect. At first, anyone with the least advantage may be sought after for information and advice, even those who may have been to Brussels on holiday may find themselves suddenly respected for the insights on the EU which may have presumably emerged from such a 'rare' experience, and these same individuals may recognize that lucrative spin-offs may be forthcoming if they assiduously and intentionally cultivate such a standing. If, as the proverb goes, in the land of the blind, the one-eyed is sovereign, then, frankly, 
there may be no one around to call one's bluff and it is relatively easy for any modest or incidental insight to be promoted as, or be mistaken for, proper expertise. Such is also more likely to happen in the least populated states, as well as those where the standard of education is low (Baldacchino, 1997: 73-6). There is bound to be a rush (by business, pressure groups, government and media) to recruit and tap the limited resources available with some modicum of European specialism; and another rush of individuals who will strategically embark on education, training, inservice programmes or placements with some EU relevance to position themselves among the new category of sought-after experts.

Such experts may also become quite adept at tapping funding as well as the certification of their expertise through regular research contracts and invitations from the European Commission itself and associated foundations. Once recognized by the Commission, they are even more likely to be recognized, and feted with awe and respect, in their own country. Do we not espy here the patterns of a virtuous cycle?

There are various stages of progress towards expertise that one may wish to identify, while keeping in mind that not every person will, or will be allowed to, or will want to, succeed in making a full transition. The point of departure is usually a situation of unconscious incompetence when the constituency does not even realise that it lacks a certain expertise. The next stage is that of conscious incompetence: in crude terms, a realization of ignorance, a condition which has rapidly come upon the citizens, policy-makers, civil servants, business and community leaders in the latest dozen EU applicant states, many of which are still coming to terms with the radical effects of their recent transition to a market economy and a pluralist democracy. The third stage is that of conscious competence, where those who have mastered the expertise go about practising and brandishing it in a self-conscious manner. The fourth and final stage is arguably that of unconscious competence, where the experts have now mastered their craft and skill so well that they 'perform' naturally, without any need for deliberate planning and problem-solving (Dreyfus and Dreyfus, 1986). What then is the impact of such experts on the unfolding of industrial relations in their home territory, if any?

\section{The Thrust of Trust}

Experts, like true professionals, require considerable autonomy to exercise their skill, even when required to do so in an employment relationship. Experts behave in a manner that assures and assumes that they are recognized as responsible for how they work, often even why they work, since they command discretion certainly on methodology and often on action agendas. The resultant 'service relationship' goes beyond the cash 
nexus and is thus invested with a considerable measure of 'trust' (Goldthorpe, 1982: 162, 170). Such a trust relationship, however, differs from the one described by Fox (1974) in labour-management relations. We are here referring to a privileged standing which also means that, typically, the contractor tends to go along with what the expert advises; indeed, it is at the point of choosing the expert in the first place (if and when such a choice is at all available) that the contractor exercises maximum leverage over the eventual service. A very charged, personalized choice tends to be made, the contractor knowing fully well that, once the choice is made, she or he has almost a moral obligation to accept, substantively and conceptually, whatever the 'expert' will then advise. After all, expertise is a most idiosyncratic market good: the value of an expert's advice is not so easily proved or disproved. The political weight of such advice, the extent to which any such expert advice will be propelled reverently, swiftly and without adulteration into policy formulation by the contracting party, will depend largely on the 'knowledge gap' between the contractor and the expert.

Of course, there are various possible permutations here: the contractors may think that they are knowledgeable, when in reality they are not; or the contractors may really be quite knowledgeable, introducing experts only to professionalize and graft some extra credibility and legitimacy to an (already adopted?) position; or again, the contractors may have some idea of what the subject matter is about, but they have come upon such knowledge incidentally or haphazardly through secondary sources. In this latter case, the contractors cannot afford the time to delve deeply into the subject, and would perhaps be willing to accept, not without chagrin, that a little knowledge is a dangerous thing. They are, therefore, bound to find themselves in a welcoming and agreeable disposition to their experts' recommendations, particularly if, as good experts habitually do, the latter bolster any proposals and recommendations with considerable supporting evidence and arguments.

Experts, from their point of view, also know that their contractors must eventually 'own' any recommendations which they put forward. Such ownership can take place in different ways: this is ideally an exercise in conviction. However, albeit rarely admitted, this may boil down simply to a question of trust and blind faith. The dynamics of such a critical transmission remain glaringly aloof from scrutiny: the manner in which experts, who 'enjoy considerable authority' (Bachrach, 1967: 78), manage the translation of their technical competence into unaccountable, political power. Where such a transmission is successful, the contractor can be relied upon to prove an ardent espouser and ambassador of the expert's recommendations. 


\section{Induced Policy Shifts}

Ardent enough to soften, perhaps even dislodge, hardened positions? Ardent enough to cause a substantial, even radical, policy shift in the attitude of the social partner in question?

Of all the EU's acquis, perhaps Chapter 13 is exceptional precisely in its manner of relinquishing overall responsibility for the substance of many obligations, by devolving such to agreements struck between the representatives of employers and workers. A typical clause in a Chapter 13 directive leaves ample room for the social partners 'to conclude ... agreements [at both national and European levels] adapting and/or complementing the provisions of this agreement in a manner which will take account of the specific needs of the social partners concerned' (Clause 6(3), Directive 97/81).

This fairly generous provision (known as the Kristoffersen clause) falls squarely within the spirit of subsidiarity promulgated by the EU, but it is also a consequence of other factors. It takes cognisance of the very diverse industrial relations frameworks, cultures and traditions in the different Member States; it captures the hesitation of various Member States towards allowing Brussels and its bureaucracy to intervene and force some standardization over an area which has to date largely escaped being considered 'of European concern', ' except at the level of pious principles. ${ }^{8}$ But, perhaps, most significantly, it reflects the status of the Agreement on Social Policy (an annexe to the Treaty of Maastricht, but an integral part of the Treaty of Amsterdam) which establishes a procedure for reaching European-level contractual agreements by the social partners which can take the place of legislation. The emergent 'framework agreements' ${ }^{\prime 9}$ are a manifestation of an upheld legitimacy for representatives of employers and labour in securing European-level deals. A similar legitimacy is recognized at national level.

My recommendations to the MEA have emphasized the opportunities for such bilateral negotiation, and the advantages of securing such deals to both trade unions and employer organizations. Indeed, my report concludes with an appeal for such 'social partnership'. Now, bilateralism is not a preferred standpoint in Maltese labour relations where nationwide issues are concerned: civil society remains weak, and a political system dominated by visible personal contacts and exchange sees politicians regularly involving themselves in labour relations disputes, with the other social actors regularly soliciting their intervention, and thus often shifting the onus for any change and reform onto the political elite. Yet there are some clear signals that the MEA will be proceeding to explore the national-level bipartism option seriously, and certainly in a specific number of areas. 


\section{Concluding Reflections}

As a self-made and market-recognized expert on EU affairs, I have found myself among the ranks of a growing expert class in Malta, as in other EU applicant and EU Member States. Many such experts have developed close links with Brussels, and their involvement in this area of knowledge is likely to have been predicated on a certain sympathy with the European project; otherwise, their attitude towards the EU and its workings may have mellowed with their increasing (lucrative?) involvement in EUrelated affairs, and their exchanges with like-minded experts from Europe. I am suggesting so because it seems to me that EU experts also tend to be largely pro-EU and, therefore, working, at least in the various applicant states, primarily in favour of their country assuming EU membership status and persevering on the road to European integration. Any movement by Maltese trade unions and employers towards 'social partnership' would be in effect a move towards convergence with the continental European social model: 'strong trade unions, wide coverage of collective bargaining, an emphasis on employee rights, tripartite regulation and some form ... of representation of employees at company level' (Gill and Krieger, 2000: 111-12). Are, therefore, 'EU experts' a hitherto unrecognized, homogenizing force in European labour relations?

Has the MEA accepted my counsel? Perhaps. But perhaps not. I may be simply deluding myself. I may have merely provided an objective crutch to support an emerging policy standpoint of a specific faction of the MEA leadership, or even of the influential MEA chief executive. The declared impetus for change may quickly subside and fall victim to other, urgent considerations. Time will tell. In the meantime, I may hazard to identify the following tentative reflections.

Is there a new European industrial relations at the dawn of the third Christian millennium? While national labour relations systems in Europe continue to demonstrate unabashed diversity (Ferner and Hyman, 1992), there are clear hints towards a convergence of coordination at a trans-European level. The inroads on European social policy in the wake of the Delors Presidency of the EU Commission, the procedures of the European Employment Strategy, the dominance of leftof-centre governments in most of the EU Member States during the 1990s, along with the accession of three corporatist states in 1995, are all likely to have contributed to this homogenizing process (Goetschy, 1999). A new 'logic of labourism' (pace Kerr et al., 1962) has been sanctioned and legitimized by a core set of EU directives, while one in particular, that setting up European Works Councils, facilitates the transnational exchange and comparison of conditions of employment in large transnational firms. The euro will further contribute to such 
benchmarking when it becomes legal tender as from 2002. 'European Industrial Relations' is coming into its own as a specific domain for research (Marginson, 2000).

The growth and consolidation of a trans-European cadre of EU experts can be regarded as both an effect and a contributor to any such convergence. Such experts may be advocating the merits of, and facilitating the transition or consolidation towards, a revamped form of social corporatism which has today become, willy-nilly, continental Europe's industrial relations benchmark.

Does a technical elite get increasingly to influence the political elite, particularly in an age dominated by a knowledge-driven economy? Is the EU itself a knowledge-driven polity and bureaucracy? If so, is a competence in EU Newspeak (Orwell, 1948) not simply a necessary condition for effective EU membership, but possibly also a ploy to facilitate European integration? Are EU experts serving as the agents of another form of 'democratic deficit' in the guise of a standardizing Europeanization, that form of institution building which is perhaps the single most important difference between the EU and other regionalisms such as NAFTA or APEC (Sweet Stone and Sandholtz, 1997), and if so, are such experts going about this mission deliberately or inadvertently?

In any case, a critical appraisal of the implications of such 'philosopherkings' (a possible characterization of politically influential intellectual capital) on avowedly democratic institutions (such as trade unions) and on the democratic process generally appears timely. If EU public policy is embedded in and animated by a politics of expertise, the exposure and analysis of such 'nested games' should further fuel the debate on issues of democracy, legitimacy, citizenship and accountability, so central to the EU project today (Marks et al., 1996).

\section{ACKNOWLEDGEMENT}

My gratitude to the organizers (especially Andreas Moschonas and Socrates Koniordos), faculty and students who participated at the Industrial Relations Summer School organized by the Jean Monnet Chair in Political Sociology at the University of Crete, Rethymno Campus, Crete, Greece, in September 2000. These proved a receptive audience and providers of welcome feedback to the ideas discussed in this article. Research support from the University of Malta is gratefully acknowledged. My sincere thanks to Simon Busuttil, Richard Hyman, Alfred Mallia Milanes and Saviour Rizzo for commenting on an earlier draft. The anonymous referees of the European Journal of Industrial Relations have also tabled useful comments. The usual disclaimers apply. 


\section{NOTES}

1 Maltese politics have been dominated by just two political parties since independence in 1964. The Nationalist Party (NP) was returned to power with $\mathbf{5 1 . 5}$ percent of the votes at the last national election, in 1998; the Malta Labour Party (MLP) secured 48.5 percent. Voter turnout, traditionally very high, was approximately 96 percent.

2 Malta applied for EU membership in 1990. In the years which followed, the NP government introduced some measures intended to bring local legislation in line with the acquis. The MLP, elected in 1996, froze the country's EU application; this was reactivated only after almost two years by the re-elected NP government. Malta had enjoyed an association agreement with the EU since 1970, but this was never taken further. Clearly, the latest 'rush' is somewhat imposed on the incumbent NP government which may prefer to secure Malta's entry to the EU before a national election becomes due, which is at the latest by the end of 2003. Note that the reactivation of Malta's EU membership bid became official in December 1998. Screening started in spring 1999 and negotiations commenced in February 2000.

3 These included three sets of familiarization visits for Maltese trade unionists to Brussels coordinated by the European Commission and an exchange with Cypriot trade union leaders. The latter was published as Symeonides and Baldacchino (1996).

4 The Malta Labour Party was invited to send a representative to MEUSAC, but refused. Nevertheless, both core group and interest group members on MEUSAC come with different political persuasions.

5 Accountants and auditors, for example, have become institutionalized experts in the wake of the regulation and standardization of company disclosure practices. Computer programmers, software developers and World Wide Web engineers are among the recent wave of experts to cultivate a leverage on the world of work and organizational development; they come in to fill the void most companies have in computer literacy and operacy, which have suddenly become such critical tools for doing business.

6 Consider the opinion (avis) or annual autumn progress report of the European Commission on each applicant state.

7 Only the 1997 Luxembourg summit formalized a European employment strategy, and specific labour relations features (such as wages and salaries, the right of association, the right to strike and the right to impose lockouts) are explicitly and assiduously defended as exclusive responsibilities of Member States.

8 The main initiatives here are the European Social Charter (approved by 11 EU Member States in 1989, and in turn based on the Council of Europe document drafted in 1961) and the framework directives on occupational health and safety.

9 To date, these include those on parental leave (December 1996), part-time workers (June 1997) and workers on fixed-term employment contracts (January 1999). 


\section{REFERENCES}

Bachrach, P. (1967) The Theory of Democratic Elitism. Boston: Little Brown. Baldacchino, G. (1997) Global Tourism and Informal Labour Relations: The Small Scale Syndrome at Work. London: Mansell.

Baldacchino, G. (2000) Malta and the European Union: A Comparative Study on Social Policy, Employment and Industrial Relations. Malta: Malta Employers Association.

Bellemare, G. (2000) 'End Users? Actors in the Industrial Relations System?', British Journal of Industrial Relations 38(3): 383-405.

Bereiter, C. and Scardamalia, M. (1993) Surpassing Ourselves: An Inquiry into the Nature and Implications of Expertise. Chicago: Open Court.

Blau, P. (1968) Bureaucracy in Modern Society. New York: Random House.

Dabscheck, G. (1995) The Struggle for Australian Industrial Relations. Oxford: Oxford University Press.

Dahrendorf, R. (1964) 'Recent Changes in the Class Structure of Modern Societies', Daedalus 93: 225-70.

Dreyfus, H.L. and Dreyfus, S.E. (1986) Mind Over Machine. New York: Free Press.

Dunlop, J.T. (1958) Industrial Relations Systems. New York: Holt.

Ferner, A. and Hyman, R. (1992) 'Industrial Relations in the New Europe: Seventeen Types of Ambiguity', in A. Ferner and R. Hyman (eds) Industrial Relations in the New Europe, pp. xvi-xlix. Oxford: Blackwell.

Fox, A. (1974) Beyond Contract: Work, Power and Trust Relations. London: Faber.

Frow, J. (1995) Cultural Studies and Cultural Value. Oxford: Oxford University Press.

Gill, C. and Krieger, H. (2000) 'Recent Survey Evidence on Participation in Europe: Towards a European Model?', European Journal of Industrial Relations 6(1): 109-32.

Goetschy, J. (1999) 'The European Employment Strategy: Genesis and Development', European Journal of Industrial Relations 5(2): 117-37.

Goldthorpe, J.H. (1982) 'On the Service Class, its Formation and Future', in A. Giddens and G. Mackenzie (eds) Social Class and the Division of Labour, Essays in Honour of Ilya Neustadt, pp. 156-75. Cambridge: Cambridge University Press.

Hyman, R. (1975) Industrial Relations: A Marxist Introduction. London: Macmillan.

Illich, I. (1977) Disabling Professions. New York: Calder and Boyars.

Kerr, C., Dunlop, J.T., Harbison, F.H. and Myers, C. (1962) Industrialism and Industrial Man. London: Heinemann.

Laffan, B. (1997) 'The European Union: A Distinctive Model of Internationalisation?', European Integration On-Line Papers 1(18): 1-17.

Lasswell, H. (1911) Politics: Who Gets What, When and How. London: Peter Smith.

Marginson, P. (2000) 'The Eurocompany and Euro Industrial Relations', European Journal of Industrial Relations 6(1): 9-34. 
Marks, G., Hooghe, L. and Blank, K. (1996) 'European Integration from the 1980s', Journal of Common Market Studies 34(3): 341-78.

Milner, A. (1999) Class. London: Sage.

Murphy, R. (1986) 'The Concept of Class in Closure Theory', Sociology 20(2): 247-64.

Orwell, G. (1948) Nineteen Eighty-Four. London: Secker and Warburg.

Perlman, S. (1928) A Theory of the Labor Movement. New York: Macmillan.

Piore, M. (1995) Beyond Individualism. Cambridge: Harvard University Press.

Strauss, A., Schatzman, L., Ehrlich, D., Bucher, R. and Sabshin, M. (1971) 'The

Hospital and its Negotiated Order', in F.G. Castles, D.J. Murray and D.C.

Potter (eds) Decisions, Organisations and Society, pp. 103-23. Milton Keynes:

Open University.

Streeck, W. (1998) 'The Internationalisation of Industrial Relations', Working Paper 98/2. Cologne: Max Planck Institute for Work and Society.

Sweet Stone, A. and Sandholtz, W. (1997) 'European Integration and

Supranational Governance', Journal of European Public Policy 4: 297-317.

Symeonides, K. and Baldacchino, G., eds (1996) Cyprus and Malta and the

Road to EU Accession: Lessons for Workers and Trade Unions. Nicosia:

Government Printer.

GODFREY BALDACCHINO is Research Officer at the Workers' Participation Development Centre and Lecturer, Department of Sociology, at the University of Malta, Malta.

ADDRESS: WPDC, University of Malta, Msida MSD 06, Malta.

[e-mail: gbal1@um.edu.mt] 